\title{
Fibrinolytic Activation Promoted by the Cyclopentapeptide Malformin: Involvement of Cytoskeletal Reorganization
}

\author{
Yukio Kolzumi, ${ }^{*} \dagger$ Hirofumi Fukudome, and Keiji Hasumi \\ Department of Applied Biological Science, Tokyo Noko University; 3-5-8 Saiwaicho, Fuchu, Tokyo 183-8509, Japan.
}

Received March 3, 2011; accepted June 9, 2011; published online June 17, 2011

\begin{abstract}
Malformin $A_{1}$, a cyclopentapeptide of fungal origin, enhances cellular fibrinolytic activity depending on the existence of a cofactor in blood plasma. However, the nature of this cofactor remains unknown. Here, we report that vitronectin acts as a plasma cofactor of malformin $A_{1}$. We purified the cofactor from bovine plasma by activity-based fractionation, and confirmed that vitronectin in conjunction with plasminogen supports the activity of malformin $A_{1}$ to promote the fibrinolytic activity of $U 937$ cells. Malformin $A_{1}$ action was abolished by Arg-GlyAsp peptide (a competitor of vitronectin-integrin binding), wortmannin (an inhibitor of signaling kinases), and cytochalasin $B$ (an inhibitor of actin polymerization). Changes in actin organization and a decrease in filopodia were observed in cells treated with malformin $A_{1}$ and plasma. A focal localization of plasminogen on the cell surface was augmented by malformin $A_{1}$, whereas the amount of cell-surface-bound plasminogen was minimally altered by the treatment. Our results suggest the involvement of cytoskeletal reorganization via vitronectin signaling in the cellular fibrinolytic activity-enhancing action of malformin $\mathbf{A}_{1}$.
\end{abstract}

Key words malformin; fibrinolysis; plasminogen; vitronectin

The fibrinolytic system contains an inactive proenzyme, plasminogen, which is converted to the active enzyme plasmin by two physiological plasminogen activators: tissue-type and urokinase-type plasminogen activators (t-PA and u-PA, respectively). Plasminogen activation mediated by t-PA is mainly involved in the dissolution of fibrin at the site of vascular injury, whereas u-PA binds to a specific cellular receptor (UPAR) and plays a role in pericellular proteolysis by activating cell-bound plasminogen. The fibrinolytic system is regulated at the level of plasminogen activators by specific inhibitors such as plasminogen activator inhibitor-1 (PAI-1), and at the level of plasmin by $\alpha_{2}$-antiplasmin. ${ }^{1)}$ This system is implicated in several pathophysiological processes, including thrombosis, inflammation, vascular repair, tissue remodeling, tumor invasion, and angiogenesis. ${ }^{2)}$

While searching for a modulator of the fibrinolytic system, we identified several low-molecular-mass compounds that effectively enhance fibrinolytic activity. ${ }^{3)}$ Malformin $A_{1}$ (Fig. 1A), a cyclic pentapeptide, is one of these compounds. ${ }^{4)}$ Malformin $A_{1}$ enhances the fibrinolytic activity of U937 human monocytoid cell line which can elaborate PA and PAI, ${ }^{5)}$ and which have been widely used to study the fibrinolytic system. The malformin effect is dependent on the existence of blood plasma, and its activity is abolished by a lysine analog that competes with plasminogen for the cell-surface receptor or fibrin, or by anti-u-PA serum. Thus, the plasminogen/u-PA system is involved in the action of malformin $A_{1}$. However, malformin $A_{1}$ does not enhance fibrinolytic activity in cellfree systems. Therefore, malformin action requires both cellular and plasma-related functions. In this study, we attempted to elucidate the activities of plasma malformin cofactor and purified vitronectin after several activity-based fractionation steps. Malformin $\mathrm{A}_{1}$ affects cytoskeletal reorganization, cell signaling, and the resultant cell-surface localization of plasminogen. This mechanism may account for the

\footnotetext{
${ }^{\dagger}$ Present address: Department of Biochemistry, Akita University Graduate School of Medicine; 1-1-1 Hondo, Akita 010-8543, Japan.
}

increase in the level of activation of cell-surface plasminogen.

\section{MATERIALS AND METHODS}

Materials Malformin $\mathrm{A}_{1}$ was isolated from a culture of Aspergillus niger $\mathrm{F} 7586$ through ethyl acetate extraction, silica gel chromatography, and reverse-phase HPLC. Plasminogen was affinity purified from human plasma, ${ }^{6}$ and the flowthrough fraction thus obtained was used as plasminogen-deficient plasma. The following materials were obtained from commercial sources: bovine vitronectin and bovine $\alpha_{2}$ macroglobulin from Yagai (Yagai, Yamagata, Japan); human fibrinogen, Arg-Gly-Asp (RGD) peptide, H-7, genistein, cytochalasin B, and nocodazole from Sigma-Aldrich (St. Louis, MO, U.S.A.); wortmannin and calphostin $\mathrm{C}$ from Kyowa Medex (Tokyo, Japan); LY294002, K252a, and PD98059 from Merck (Darmstadt, Germany); U-73122 from Wako (Osaka, Japan); Texas Red-X phalloidin from Invitrogen (Carlsbad, CA, U.S.A.); and t-butyloxycarbonyl-Val-LeuLys-4-methyl-coumaryl-7-amide (Boc-VLK-MCA) from Peptide Institute (Osaka, Japan). U937 cells were obtained from the Japanese Collection of Research Bioresources (Osaka, Japan). Cells were cultured in suspension in RPMI1640 medium supplemented with $10 \%$ fetal bovine serum (JRH Biosciences, Lenexa, KS, U.S.A.), 100 units $/ \mathrm{ml}$ penicillin, and $100 \mu \mathrm{g} / \mathrm{ml}$ streptomycin. Exponentially growing cells were used for the experiments.

Assay for Cellular Fibrinolytic Activity ${ }^{125}$ I-Fibrincoated 96-well plates were prepared using ${ }^{125}$ I-fibrinogen $(\mathrm{ca}$. $2000 \mathrm{cpm} / \mu \mathrm{g}$ ) as described previously. ${ }^{7)}$ Each well received $50-80 \mu \mathrm{l}$ of reaction mixture containing U937 cells (5X $10^{6} / \mathrm{ml}$ ) and the indicated concentrations of human plasma or plasminogen in phosphate-buffered saline (PBS) $(20 \mathrm{~mm}$ sodium phosphate and $150 \mathrm{~mm} \mathrm{NaCl}, \mathrm{pH} 7.4$ ) containing gelatin $(2.5 \mathrm{mg} / \mathrm{ml})$. After incubation for $3 \mathrm{~h}$ at $37^{\circ} \mathrm{C}$ in the absence or presence of malformin $\mathrm{A}_{1}(5.0 \mu \mathrm{M})$, the radioactivity released was measured in terms of the amount of degraded 
${ }^{125}$ I-fibrin. Where indicated, vitronectin, $\alpha_{2}$-macroglobulin, RGD peptide, and/or fibronectin were added to the reaction mixture at the indicated concentrations. In experiments using various inhibitors, cells were pretreated with an inhibitor at the indicated concentration for $5 \mathrm{~min}$ at $22^{\circ} \mathrm{C}$.

Purification of Malformin Cofactor from Plasma Bovine citrated plasma $(61 \mathrm{ml})$ was fractionated according to the ethanol precipitation method of Cohn et al. ${ }^{8)}$ Malformin cofactor activity was present in the IV-1 fraction of the precipitate wherein $\mathrm{ca}$. $6 \%$ of the total amount of plasma proteins was recovered. After dialysis, the IV-1 fraction was treated with ammonium sulfate, and precipitates formed in the $25-50 \%$ saturation fraction were subjected to ionexchange chromatography on Protein PAK G-DEAE $(20 \times 100 \mathrm{~mm}$; Waters, Milford, MA, U.S.A. $)$. The column was developed with a linear gradient of $\mathrm{NaCl}(0-1.0 \mathrm{M})$ in $50 \mathrm{~mm}$ Tris- $\mathrm{HCl}, \mathrm{pH} \mathrm{7.4}$, and the tailing edge of the main protein peak was pooled. After concentration, the pooled fraction was subjected to hydrophobic interaction chromatography on Protein PAK G-Butyl $(8.2 \times 75 \mathrm{~mm}$; waters). Proteins were eluted with a linear negative gradient of ammonium sulfate $(1.3-0 \mathrm{~m})$ in $50 \mathrm{~mm}$ Tris- $\mathrm{HCl}, \mathrm{pH}$ 7.4. The fractions expressing malformin cofactor activity were further purified on TSK G3000SW $(7.5 \times 600 \mathrm{~mm}$; Tosoh, Tokyo, Japan). The flow-through fraction yielded $0.16 \mathrm{mg}$ of partially purified malformin cofactor.

Assay for Cellular Plasminogen Activation Cellular plasminogen activation was determined as the activity required to catalyze the cleavage of Boc-VLK-MCA, a fluorogenic substrate for plasmin. A reaction mixture containing U937 cells $\left(5 \times 10^{6} / \mathrm{ml}\right)$, plasminogen $(50 \mathrm{~nm})$, and Boc-VLKMCA $(20 \mu \mathrm{M})$ in PBS containing $1.5 \mathrm{mg} / \mathrm{ml}$ gelatin was incubated in the absence or presence of vitronectin $(30 \mu \mathrm{g} / \mathrm{ml})$ or malformin $\mathrm{A}_{1}(5.0 \mu \mathrm{M})$. After incubation for $2 \mathrm{~h}$ at $37^{\circ} \mathrm{C}$, fluorescence (excitation, $365 \mathrm{~nm}$; emission, $450 \mathrm{~nm}$ ) was measured using a model MTP-32 fluorescence microplate reader (Corona Electric, Ibaraki, Japan).

Fluorescence Imaging For actin cytostaining, U937 cells $\left(5 \times 10^{6} / \mathrm{ml}\right)$ were incubated in PBS containing gelatin $(2.5 \mathrm{mg} / \mathrm{ml})$ and human plasma $(20 \%(\mathrm{v} / \mathrm{v}))$ in the absence or presence of malformin $\mathrm{A}_{1}(5.0 \mu \mathrm{M})$ on fibrin-coated coverslips for $2 \mathrm{~h}$ at $37^{\circ} \mathrm{C}$. After the medium was removed, the cells were fixed with paraformaldehyde $(3.7 \%(\mathrm{w} / \mathrm{v}))$ for $20 \mathrm{~min}$ at $22^{\circ} \mathrm{C}$. The cells were subsequently washed with PBS, permeabilized with Triton X-100 (0.1\% (w/v)) for $5 \mathrm{~min}$, and incubated with Texas Red-X phalloidin $(0.25 \mu \mathrm{g} / \mathrm{ml})$ for $20 \mathrm{~min}$ in the dark. To image cell-surface plasminogen, U937 cells $\left(5 \times 10^{6} / \mathrm{ml}\right)$ were incubated with plasminogen-deficient plasma $(20 \%(\mathrm{v} / \mathrm{v}))$ in the absence or presence of malformin $\mathrm{A}_{1}(5.0 \mu \mathrm{M})$ for $2 \mathrm{~h}$ at $37^{\circ} \mathrm{C}$. After washing, the cells were incubated with Alexa Fluor 594-labeled plasminogen $(100 \mathrm{~nm})$ for $2 \mathrm{~h}$ at $37^{\circ} \mathrm{C}$. The cells were washed, bound to poly-lysine-coated coverslips by gentle centrifugation, and fixed with paraformaldehyde for $20 \mathrm{~min}$ at $22{ }^{\circ} \mathrm{C}$. Fluorescence imaging was performed on a confocal laser scanning microscope TCS NT (Leica Microsystems AG, Wetzlar, Germany).

Flow Cytometry U937 cells were bound to Alexa 594plasminogen as described above. After washing with PBS and fixing with paraformaldehyde for $20 \mathrm{~min}$ at $22^{\circ} \mathrm{C}$, flow cytometric analysis was performed on EPICS Elite (Beck- man Coulter, Fullerton, CA, U.S.A.).

Other Methods Fibrinogen and plasminogen were radioiodinated using the iodine monochloride method. ${ }^{9}$ ) Plasminogen was fluorescence labeled using Alexa Fluor 594 Protein Labeling Kit (Invitrogen). The $\mathrm{NH}_{2}$-terminal amino acid sequence was determined after transferring the proteins to polyvinylidene difluoride membranes by using a protein sequencer model 476A (Applied Biosystems, Carlsbad, CA, U.S.A.). The binding of ${ }^{125} \mathrm{I}$-plasminogen to U937 cells was determined as described previously. ${ }^{7)}$

Statistical Analysis Data were expressed as the mean \pm standard deviation (S.D.). The significant differences were analyzed using the $t$-test. $p$ values of $<0.05$ were considered significant.

\section{RESULTS}

Purification of Plasma Cofactor for Malformin Action The promotion of cellular fibrinolytic activity by malformin $\mathrm{A}_{1}$ requires blood plasma (Fig. 1B). Our previous experiments demonstrate that 6-aminohexanoic acid, a lysine ana$\log$ that inhibits plasminogen-fibrin binding, abolishes the action of malformin $\mathrm{A}_{1}$. ${ }^{4}$ However, as shown in Fig. 1B, plasminogen alone did not support the action of malformin $A_{1}$. Thus, these results suggest the presence of an additional plasma cofactor required for action of malformin. We tried to purify this cofactor from bovine plasma, which is also able to support malformin activity. The cofactor was purified using ethanol precipitation and ammonium sulfate fractionation, followed by ion-exchange, hydrophobic interaction, and gel filtration chromatographies (Figs. 1C-E). Starting with $61 \mathrm{ml}$ of plasma, $0.16 \mathrm{mg}$ of partially purified preparation was obtained with a 536-fold increase in specific activity (Fig. 1F). The final preparation yielded two major protein bands at approximately 78 and $180 \mathrm{kDa}$ on reduced SDSpolyacrylamide gel electrophoresis (Fig. 1G); the two proteins were identified as vitronectin ${ }^{10)}$ and $\alpha_{2}$-macroglobulin, ${ }^{11)}$ respectively, on the basis of their $\mathrm{NH}_{2}$-terminal amino acid sequences (Fig. 1G).

Identification and Characterization of Vitronectin as a Plasma Cofactor To determine which protein serves as a malformin cofactor, purified preparations of vitronectin and $\alpha_{2}$-macroglobulin obtained from commercial sources were assayed for their activity in promoting malformin $\mathrm{A}_{1}$-dependent enhancement of cellular fibrinolytic activity. As shown in Fig. 2A, vitronectin or $\alpha_{2}$-macroglobulin alone was ineffective. On the other hand, vitronectin supported the action of malformin $\mathrm{A}_{1}$ in the presence of plasminogen, whereas $\alpha_{2}$-macroglobulin was ineffective even in the presence of plasminogen (Fig. 2A). While the physiological plasma concentration of vitronectin is $100-400 \mu \mathrm{g} / \mathrm{ml},{ }^{12)}$ the minimum concentration of vitronectin as a malformin cofactor was $10 \mu \mathrm{g} / \mathrm{ml}$ (Fig. 2B). Consistent with the effect of malformin on cellular fibrinolytic activity, the activity of malformin $A_{1}$ for enhancing plasminogen activation on U937 cells was observed in the presence of vitronectin (Fig. 2C).

Vitronectin is implicated in cell adhesion, spreading, and migration as well as extracellular matrix anchoring, immune defense, and hemostasis/fibrinolysis. ${ }^{13,14)}$ Particular domains in vitronectin play distinct roles in each of these activities. Among these, the domain containing the RGD motif is im- 
A

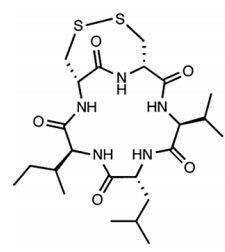

Malformin $\mathrm{A}_{1}$
B

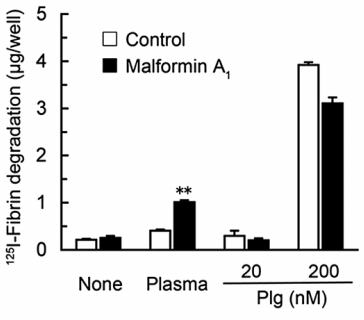

E

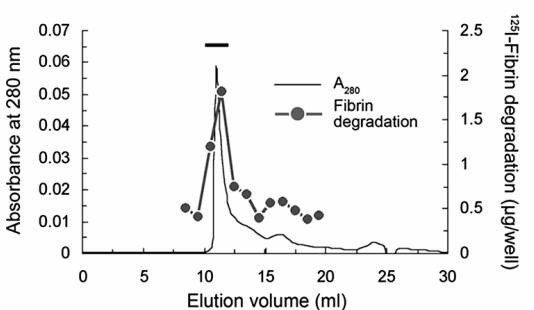

C

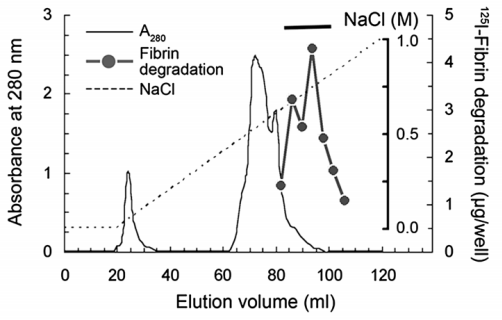

F

\begin{tabular}{lcccc}
\multicolumn{5}{c}{ Purification of plasma cofactor } \\
\hline Step & $\begin{array}{c}\text { Protein } \\
\text { (mg) }\end{array}$ & $\begin{array}{c}\text { Total } \\
\text { activity } \\
\text { (unit) }\end{array}$ & $\begin{array}{c}\text { Specific } \\
\text { activity } \\
\text { (unit/mg) }\end{array}$ \\
\hline Plasma & 5,642 & 5,664 & 1.0 & 100 \\
EtOH ppt. \& $\left(\mathrm{NH}_{4}\right)_{2} \mathrm{SO}_{4}$ & 105 & 5,429 & 52 & 96 \\
lon-exchange & 6.9 & 868 & 126 & 15 \\
Hydrophobic interaction & 0.33 & 134 & 406 & 2.4 \\
Gel filtration & 0.16 & 85.7 & 536 & 1.5 \\
\hline
\end{tabular}

D

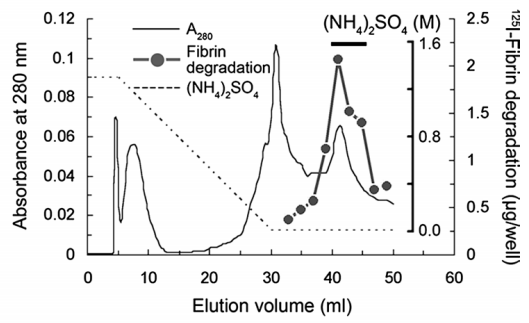

G

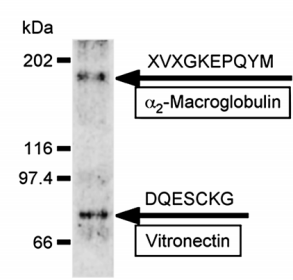

Fig. 1. Purification of Malformin Cofactor from Bovine Plasma

(A) Structure of malformin $A_{1}$. (B) Malformin $A_{1}$ action requires a plasma cofactor other than plasminogen. U937 cells were incubated on ${ }^{125}$ I-fibrin-coated plates in the absence or presence of human plasma $(20 \%(\mathrm{v} / \mathrm{v}))$ and plasminogen $(20$ or $200 \mathrm{nM})$. After incubation in the absence or presence of malformin $\mathrm{A}_{1}(5.0 \mu \mathrm{M})$, the amount of ${ }^{125} \mathrm{I}-\mathrm{fibrin}$ that had degraded was determined. Error bars represent S.D. from triplicate determinations. Statistical analysis was performed by a $t$-test (** $p<0.05)$. (C) Ion-exchange chromatography on Protein PAK G-DEAE. The $\left(\mathrm{NH}_{4}\right)_{2} \mathrm{SO}_{4}$ fraction (25-50\% saturation) was subjected to chromatography. (D) Hydrophobic interaction chromatography on Protein PAK G-Butyl. The pooled DEAE fraction (bar on panel C) was subjected to chromatography. (E) Gel filtration chromatography on TSK G3000SW. After concentration, the pooled fraction (bar on panel D) was applied. (F) Summary of the purification from $61 \mathrm{ml}$ of bovine plasma. One unit of cofactor activity was defined as the amount that causes a 2-fold increase in U937 cell-mediated fibrin degradation in the presence of malformin $A_{1}(5.0 \mu \mathrm{M})$. (G) SDS-polyacrylamide gel electrophoresis of the final preparation. The flow-through fraction of the gel filtration (bar on panel E) was resolved on a $7.5 \%$ gel under reduced condition. $\mathrm{NH}_{2}$-terminal amino acid sequences of major bands are shown. $X$ denotes an unidentified amino acid.

A

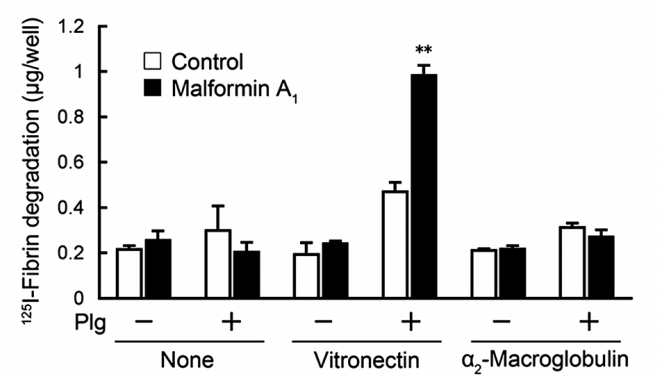

C

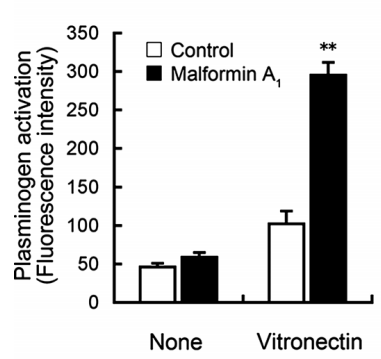

D

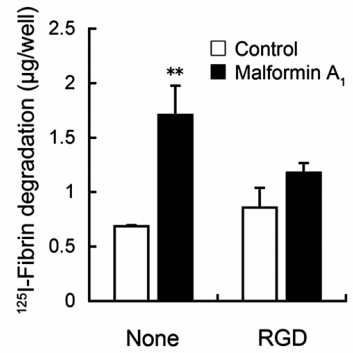

B

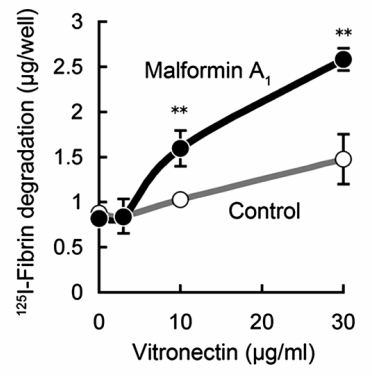

$\mathrm{E}$

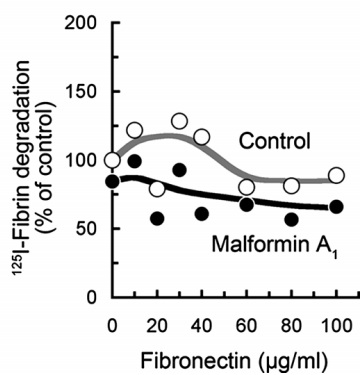

Fig. 2. Identification and Characterization of Vitronectin as a Plasma Cofactor

(A) Identification of vitronectin as a plasma cofactor. U937 cells were incubated with vitronectin ( $30 \mu \mathrm{g} / \mathrm{ml})$ or $\alpha_{2}$-macroglobulin ( $\left.30 \mu \mathrm{g} / \mathrm{ml}\right)$ in the absence or presence of plasminogen $(\mathrm{Plg}, 20 \mathrm{nM})$ and/or malformin $\mathrm{A}_{1}(5.0 \mu \mathrm{M})$ to determine ${ }^{125}$ I-fibrin degradation. (B) Dose dependency of vitronectin activity. U937 cells were incubated with plasminogen $(20 \mathrm{nM})$ and the indicated concentrations of vitronectin in the absence or presence of malformin $\mathrm{A}_{1}(5.0 \mu \mathrm{M})$ to determine ${ }^{125} \mathrm{I}$-fibrin degradation. (C) Cellular plasminogen activation. U937 cells were incubated with plasminogen $(50 \mathrm{nM})$ and Boc-VLK-MCA $(20 \mu \mathrm{M})$ in the absence or presence of vitronectin $(30 \mu \mathrm{g} / \mathrm{ml})$ or malformin $\mathrm{A}_{1}(5.0 \mu \mathrm{M})$ to determine plasminogen activation. (D) Inhibition of vitronectin cofactor activity by RGD peptide. U937 cells were incubated with plasminogen ( $20 \mathrm{nM})$ and vitronectin (30 $\mu \mathrm{g} / \mathrm{ml})$ in the absence or presence of RGD peptide $(2.0 \mathrm{~mm})$ and/or malformin $\mathrm{A}_{1}(5.0 \mu \mathrm{M})$ to determine ${ }^{125}$ I-fibrin degradation. (E) Fibronectin failed to support the action of malformin $\mathrm{A}_{1}$. U937 cells were incubated with plasminogen $(20 \mathrm{nM})$ and the indicated concentrations of fibronectin in the absence or presence of malformin $\mathrm{A}_{1}(5.0 \mu \mathrm{M})$ to determine ${ }^{125} \mathrm{I}$-fibrin degradation. Data are from two experiments with single incubation. The value representing $100 \%$ was $0.22 \pm 0.03 \mu \mathrm{g} /$ well. Error bars in panels A-D represent S.D. from triplicate determinations. Statistical analyses were performed by a $t$-test $(* * p<0.05)$ 

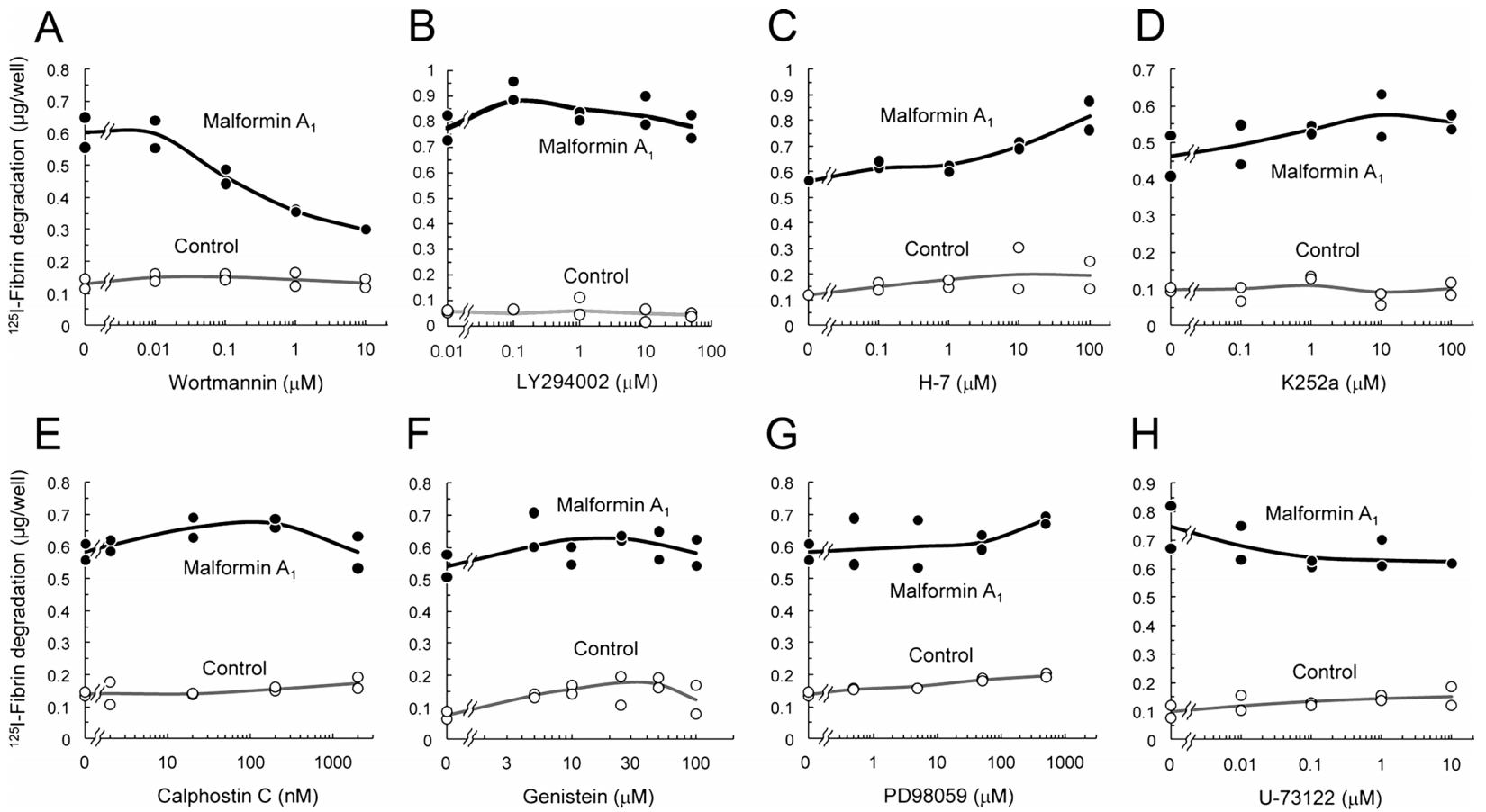

Fig. 3. Effects of Cell Signaling Inhibitors on Malformin $\mathrm{A}_{1}$ Action

U937 cells were pretreated for 5 min at $22^{\circ} \mathrm{C}$ with wortmannin (A), LY294002 (B), H-7 (C), K252a (D), calphostin C (E), genistein (F), PD98059 (G), or U-73122 (H) at the indicated concentrations. The pretreated cells were incubated with human plasma $(20 \%, \mathrm{v} / \mathrm{v})$ in the absence or presence of malformin $\mathrm{A}_{1}(5.0 \mu \mathrm{M})$ to determine ${ }^{125} \mathrm{I}$-fibrin degradation. Values from duplicate determinations are shown.

portant in the interaction between vitronectin and integrins. The RGD peptide competes with vitronectin for binding to integrins. As shown in Fig. 2D, the RGD peptide inhibited vitronectin-dependent malformin $A_{1}$ action. Thus, the interaction between vitronectin and cellular integrin(s) seems to be essential for the action of malformin $\mathrm{A}_{1}$. Like vitronectin, fibronectin has the RGD motif and can act as an adhesion molecule via interactions with the integrins. ${ }^{15)}$ However, fibronectin did not exhibit any malformin cofactor activity (Fig. 2E).

Effects of Cell-Signaling Inhibitors The binding of vitronectin to cell-surface integrins results in intracellular signaling events. Next, we investigated the possible involvement of cell signaling in malformin action by using several inhibitors. Among the inhibitors tested, wortmannin, an inhibitor of phosphatidylinositol (PtdIns) 3-kinase, abolished the effect of malformin at high concentrations $(>0.1 \mu \mathrm{M})$, whereas the agent was ineffective at $0.01 \mu \mathrm{M}-\mathrm{a}$ concentration widely used to inhibit PtdIns 3-kinase (Fig. 3A). ${ }^{16)}$ Furthermore, LY294002 (another inhibitor of PtdIns 3-kinase) did not inhibit the malformin effects (Fig. 3B). Thus, a wortmannin-sensitive kinase(s) other than PtdIns 3-kinase seems to be involved in malformin action. In the absence of malformin $A_{1}$, wortmannin did not affect cellular fibrinolytic activity, even at concentrations as high as $10 \mu \mathrm{M}$. H-7, an inhibitor of protein kinases A, C, and G, slightly potentiated malformin activity (Fig. 3C). K252a (an inhibitor of protein kinases A, C, and $\mathrm{G}$ and myosin light chain kinase), calphostin $C$ (a specific inhibitor of protein kinase $C$ ), genistein (an inhibitor of tyrosine kinases), PD98059 (an inhibitor of mitogen-activated protein kinase kinase), and U-73122 (an inhibitor of phospholipase C) minimally affected the action of malformin $\mathrm{A}_{1}$ (Figs. 3D-H).
Involvement of Cytoskeletal Reorganization Cytoskeletal changes follow the binding of vitronectin to integrins and subsequent signaling events. ${ }^{17}$ ) The major components of the cytoskeleton are actin and tubulin. Malformin action was abolished by the actin polymerization inhibitor, cytochalasin $\mathrm{B}$, while nocodazole, an inhibitor of tubulin polymerization, had no effect (Fig. 4A). The cytostaining experiments demonstrate that actin fibers support the formation of cellsurface filopodia-like structures in control cells (Fig. 4B, left). In contrast, such protrusions disappeared in the malformin $\mathrm{A}_{1}$-treated cells, and the surface of these treated cells appeared smooth (Fig. 4B, right). These results suggest that the actin cytoskeleton is reorganized because of malformin $\mathrm{A}_{1}$ activity.

Alteration of Cell-Surface Plasminogen Localization One of the possible mechanisms that lead to the activation of fibrinolysis accompanied by cytoskeletal changes is alteration of the cell-surface localization of the fibrinolytic components. The importance of local plasminogen accumulation in the fibrinolytic process is well documented. ${ }^{18)}$ When U937 cells were treated with Alexa 594-plasminogen in plasminogen-deficient plasma, partial focal localization of labeled plasminogen was observed (Fig. 5A, upper). In the presence of malformin $A_{1}$, the focal localization of plasminogen was more prominent (Fig. 5A, lower). Flow cytometric analysis revealed a slight increase (1.2-fold) in plasminogen binding in the malformin $A_{1}$-treated cells (Fig. 5B). Malformin $A_{1}$ did not enhance the binding of ${ }^{125}$ I-plasminogen to U937 cells in an independent experiment (Fig. 5C). Thus, it seems probable that alteration of the cell-surface localization of plasminogen, which leads to its local accumulation, is a key process in malformin $\mathrm{A}_{1}$-induced fibrinolytic activation. 


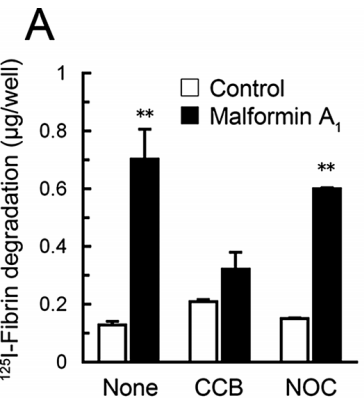

B
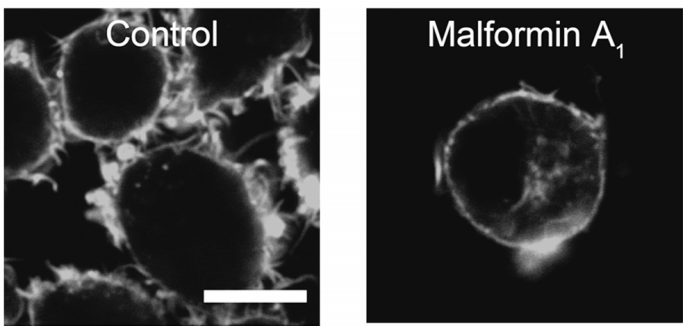

Fig. 4. Involvement of Actin Cytoskeletal Reorganization in Malformin Action

(A) Effects of cytoskeletal disruptants. U937 cells were pretreated with cytochalasin B (CCB, $50 \mu \mathrm{M})$ or nocodazole (NOC, $5.0 \mu \mathrm{M})$ for 5 min at $22{ }^{\circ} \mathrm{C}$. The pretreated cells were incubated with human plasma $(20 \%, \mathrm{v} / \mathrm{v})$ in the absence or presence of malformin $\mathrm{A}_{1}(5.0 \mu \mathrm{M})$ to determine ${ }^{125} \mathrm{I}$-fibrin degradation. Error bars represent S.D. from triplicate determinations. Statistical analysis was performed by a $t$-test $(* * p<0.05)$. (B) Actin cytostaining. U937 cells were incubated with human plasma $(20 \%(\mathrm{v} / \mathrm{v}))$ in the absence $($ left $)$ or presence (right) of malformin $\mathrm{A}_{1}(5.0 \mu \mathrm{M})$ on fibrin-coated coverslips. After incubation, the cells were fixed, permeabilized, and treated with Texas Red-X phalloidin to visualize actin cytoskeletons. Bar, $5 \mu \mathrm{m}$.

A
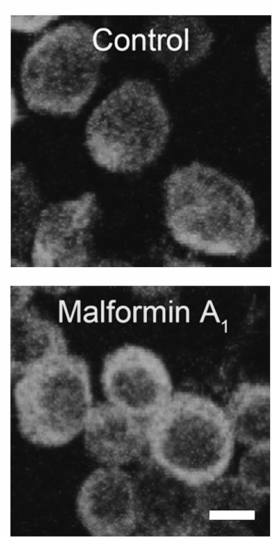

B

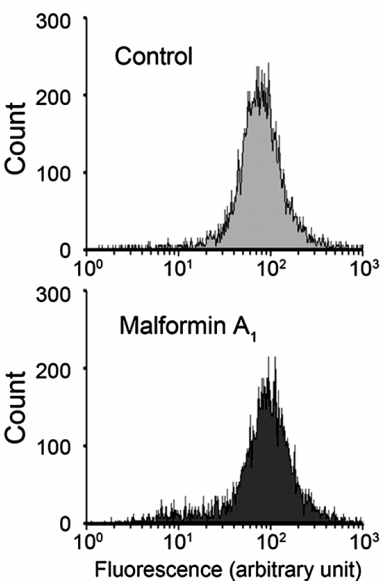

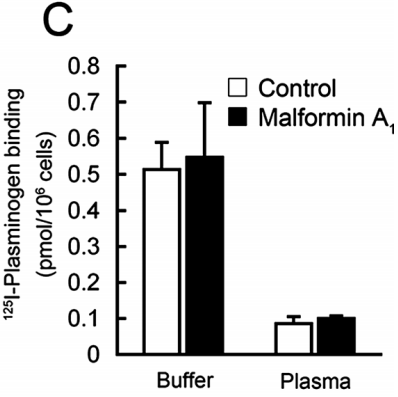

Fig. 5. Alteration of Cell-Surface Plasminogen Localization

(A) Cell-surface plasminogen localization. U937 cells were incubated with plasminogen-deficient plasma (20\% (v/v)) in the absence (upper) or presence (lower) of malformin $\mathrm{A}_{1}$ $(5.0 \mu \mathrm{M})$. After washing, the cells were incubated with Alexa 594-plasminogen (100 nM). Bar, $5 \mu \mathrm{m}$. (B) Capacity of plasminogen binding as determined by flow cytometry. U937 cells were bound to Alexa 594-plasminogen as in (A) and subjected to flow cytometry. The peaks of fluorescence (arbitrary units) were 76 and 93 in control and malformin $\mathrm{A}_{1-}$ treated cells, respectively. (C) Capacity of plasminogen binding as determined using ${ }^{125} \mathrm{I}$-plasminogen. U937 cells were incubated with ${ }^{125} \mathrm{I}$-plasminogen $(200$ nM) in buffer or plasma $(20 \%(\mathrm{v} / \mathrm{v}))$ in the absence or presence of malformin $\mathrm{A}_{1}(5.0 \mu \mathrm{M})$ to determine plasminogen binding. Error bars represent S.D. from triplicate determinations.

\section{DISCUSSION}

Our previous experiments suggest that malformin $A_{1}$ enhances fibrinolytic activity depending on cellular function and the existence of blood plasma. ${ }^{4)}$ This property of malformin $A_{1}$ is similar to that of plactin, another cyclic pentapeptide that enhances cellular fibrinolytic activity with the aid of a plasma cofactor. ${ }^{3,19,20)}$ Prothrombin and a proenzyme form of plasma hyaluronan-binding protein (factor VII-activating protease) have been identified as independent plactin cofactors in plasma. Plactin leads to cell-surface single-chain $\mathrm{u}-\mathrm{PA}$ activation by promoting the activation of these zymogens. ${ }^{20,21)}$ However, malformin action does not involve the activation of u-PA. ${ }^{4)}$ Our results clearly demonstrate that malformin $A_{1}$ utilizes a distinct mechanism to promote fibrinolytic activity with vitronectin as a plasma cofactor. It is likely that vitronectin acts through binding to cell-surface integrins since the RGD peptide, a competitor of vitronectinintegrin interaction, abolishes the vitronectin-dependent malformin action (Fig. 2D). In addition, inhibition of cell signaling by wortmannin (Fig. 3A) and disruption of cytoskeletal organization by cytochalasin (Fig. 4A) diminish malformin activity. Since cellular binding of vitronectin leads to a cellsignaling event and subsequent cytoskeletal reorganization, ${ }^{17}$ ) the collective interpretation of these results indicate that vitronectin-mediated cytoskeletal reorganization is required for malformin action. The final consequence of vitronectin-dependent malformin action is likely to be the alteration of plasminogen localization on the cell surface (Fig. 5A). This change may account for an increase in cell-surface plasminogen activation (Fig. 2C). Although cytoskeletal reorganization is implicated in cellular fibrinolytic activity through changes in u-PA expression, ${ }^{22,23)}$ the possibility that malformin increases u-PA activity is excluded. ${ }^{4)}$ The inhibition of cellular protein synthesis did not affect the activity of malformin (data not shown).

Vitronectin can stabilize PAI- $1,{ }^{24)}$ and therefore, affect the fibrinolytic system by enhancing plasminogen activator neutralization. In our experiments, vitronectin increased the fibrinolytic activity of U937 cells, but did not decrease even in the absence of malformin $\mathrm{A}_{1}$ (Figs. 2A, B). Thus, the stabilization of PAI-1 by vitronectin may not be significant in our 
system; alternatively, this antifibrinolytic effect can be overcome by a hitherto uncharacterized profibrinolytic action of vitronectin. It is unlikely that the activity of malformin is due to the modulation of PAI-1 stabilization by vitronectin since malformin action is abolished by inhibitors of vitronectin-integrin binding, cell signaling, and cytoskeletal organization. The cellular binding of vitronectin can alternatively occur via uPAR. ${ }^{25)}$ Unlike vitronectin-integrin interactions, this binding is not inhibited by the RGD peptide. ${ }^{25)}$ Thus, it is also unlikely that the activity of malformin involves vitronectin binding to uPAR.

Integrins recognize the RGD epitope in various extracellular matrix proteins. Fibronectin, an RGD-containing protein, plays a role in cell adhesion, migration, and proliferation. Fibronectin-integrin binding triggers cell signaling and cytoskeletal reorganization. ${ }^{26)}$ Although these effects are similar to those caused by vitronectin, fibronectin failed to promote malformin $\mathrm{A}_{1}$-dependent fibrinolytic enhancement in U937 cells (Fig. 2E). Vitronectin can bind to the integrins $\alpha_{\mathrm{V}} \beta_{5}$ and $\alpha_{\mathrm{V}} \beta_{8}$, which are not involved in fibronectin binding (the fibronectin-binding integrins are of the subtypes $\alpha_{3} \beta_{1}$, $\alpha_{4} \beta_{1}, \alpha_{5} \beta_{1}, \alpha_{8} \beta_{1}, \alpha_{9} \beta_{1}, \alpha_{\mathrm{IIb}} \beta_{3}, \alpha_{\mathrm{V}} \beta_{1}, \alpha_{\mathrm{V}} \beta_{3}$, and $\alpha_{\mathrm{V}} \beta_{6}$; while the vitronectin-binding integrins are of the subtypes $\alpha_{8} \beta_{1}$, $\alpha_{\mathrm{IIb}} \beta_{3}, \alpha_{\mathrm{V}} \beta_{1}, \alpha_{\mathrm{V}} \beta_{3}, \alpha_{\mathrm{V}} \beta_{5}, \alpha_{\mathrm{V}} \beta_{6}$, and $\left.\alpha_{\mathrm{V}} \beta_{8}\right)$. Thus, vitronectin-specific integrin signaling may be involved in malformin action. Vitronectin-integrin binding is followed by cell-signaling events. Among the signaling inhibitors tested in this study, only wortmannin was effective in suppressing malformin action (Fig. 3A). Wortmannin is an inhibitor of PtdIns 3-kinase, while the high concentration of wortmannin $(0.1-1.0 \mu \mathrm{M})$ can inhibit PtdIns 4-kinase that provides PtdIns 4-monophosphate and PtdIns 4,5-bisphosphate, which regulate cytoskeletal rearrangement, ${ }^{27-29)}$ and myosin lightchain kinase, which is implicated in the integrin signaling. ${ }^{30)}$ Malformin action is inhibited by wortmannin at high concentrations $(1.0 \mu \mathrm{M})$. Malformin may modulate a cell-signaling event mediated by one of the kinases that is inhibited by higher concentrations of wortmannin.

Malformin was first identified as a fungal metabolite that induces curvature in plant roots. However, the molecular mechanism underlying its activity remains unknown. Recent reports state that malformin affects the $G_{2}$ checkpoint in the cell cycle after DNA damage. ${ }^{31)}$ Since cell cycle regulation involves signaling events, this suggests the presence of a target for malformin shared by vitronectin signaling and cell cycle regulation. It is tempting to speculate that the action of malformin on cell signaling plays a role in the induction of malformation in plant roots.

Acknowledgements The authors thank Nozomi Ichikawa and Kenji Okuda for technical assistance. Human plasma was kindly provided by the Japanese Red Cross Society, Tachikawa, Tokyo. This work was supported by a Grantin-Aid for Scientific Research from the Ministry of Education, Culture, Sports, Science and Technology of Japan.

\section{REFERENCES}

1) Rijken D. C., Lijnen H. R., J. Thromb. Haemost., 7, 4-13 (2009).

2) Castellino F. J., Ploplis V. A., Thromb. Haemost., 93, 647-654 (2005).

3) Hasumi K., Yamamichi S., Harada T., FEBS J., 277, 3675-3687 (2010).

4) Koizumi Y., Hasumi K., J. Antibiot., 55, 78-82 (2002).

5) Vassalli J. D., Dayer J. M., Wohlwend A., Belin D., J. Exp. Med., 159, 1653-1668 (1984).

6) Deutsch D. G., Mertz E. T., Science, 170, 1095-1096 (1970).

7) Tachikawa K., Hasumi K., Endo A., Thromb. Haemost., 77, 137-142 (1997).

8) Cohn E. J., Strong L. E., Hughes W. L., Mulford D. J., Ashworth J. N., Melin M., Taylor H. L., J. Am. Chem. Soc., 68, 459- 475 (1946).

9) Goldstein J. L., Basu S. K., Brown M. S., Methods Enzymol., 98, 241-260 (1983)

10) Hayman E. G., Pierschbacher M. D., Suzuki S., Ruoslahti E., Exp. Cell Res., 160, 245-258 (1985)

11) Shibata M., Sakai H., Sakai E., Okamoto K., Nishishita K., Yasuda Y., Kato Y., Yamamoto K., Eur. J. Biochem., 270, 1189-1198 (2003).

12) Barnes D. W., Silnutzer J., J. Biol. Chem., 258, 12548-12552 (1983).

13) Preissner K. T., Seiffert D., Thromb. Res., 89, 1-21 (1998)

14) Schvartz I., Seger D., Shaltiel S., Int. J. Biochem. Cell Biol., 31, 539544 (1999).

15) Pierschbacher M. D., Ruoslahti E., Nature (London), 309, 30-33 (1984).

16) Arcaro A., Wymann M. P., Biochem. J., 296, 297-301 (1993).

17) Miranti C. K., Brugge J. S., Nat. Cell Biol., 4, 83-90 (2002).

18) Sakharov D. V., Nagelkerke J. F., Rijken D. C., J. Biol. Chem., 271, $2133-2138(1996)$

19) Inoue T., Hasumi K., Sugimoto M., Endo A., Thromb. Haemost., 79, $591-596$ (1998).

20) Harada T., Tsuruta T., Yamagata K., Inoue T., Hasumi K., FEBS J., 276, 2516-2528 (2009)

21) Yamamoto E., Yamamichi S., Choi-Miura N. H., Hasumi K., Thromb. Res., 126, 406-413 (2010).

22) Irigoyen J. P., Besser D., Nagamine Y., J. Biol. Chem., 272, 1904 1909 (1997).

23) Shinohara C., Chikanishi T., Nakashima S., Hashimoto A., Hamanaka A., Endo A., Hasumi K., J. Antibiot., 53, 262-268 (2000).

24) Declerck P. J., De Mol M., Alessi M. C., Baudner S., Pâques E. P., Preissner K. T., Müller-Berghaus G., Collen D., J. Biol. Chem., 263, 15454-15461 (1988).

25) Waltz D. A., Chapman H. A., J. Biol. Chem., 269, 14746-14750 (1994).

26) Wierzbicka-Patynowski I., Schwarzbauer J. E., J. Cell Sci., 116 3269-3276 (2003).

27) Meyers R., Cantley L. C., J. Biol. Chem., 262, 4384-4390 (1997)

28) Lassing I., Lindberg U., Nature (London), 314, 472- 474 (1985).

29) Janmey P. A., Stossel T. P., Nature (London), 325, 362-364 (1987).

30) Nakanishi S., Kakita S., Takahashi I., Kawahara K., Tsukuda E., Sano T., Yamada K., Yoshida M., Kase H., Matsuda Y., Hashimoto Y., Nonomura Y., J. Biol. Chem., 267, 2157-2163 (1992).

31) Hagimori K., Fukuda T., Hasegawa Y., Omura S., Tomoda H., Biol. Pharm. Bull., 30, 1379-1383 (2007). 